\title{
TWIN DEFICIT HYPOTHESIS AND MACROECONOMIC FUNDAMENTALS: NEW EVIDENCE FROM NIGERIA
}

Taofeek Olusola
AYINDE ${ }^{1+}$
iD Muritala Olayemi
OGUNSIJI $^{2}$
ID Kaosarat
Olawunmi $^{\text {IBIKUNLE }}{ }^{s}$

\section{Article History}

Received: 4 June 2021 Revised: 7 July 2021

Accepted: 9 August 2021

Published: 2 September 2021

\section{Keywords}

Current account deficits

Fiscal deficits

Exchange rate

Interest rate

Economy openness

Autoregressive model

Structural model.

\section{JEL Classification:}

F32; H62; F31; E42; F41; C22.

\author{
${ }^{1,2}$ Lecturer and Researcher, Department of Economics, Fountain University, \\ Oke-Osun, Osogbo, Osun State, Nigeria. \\ ${ }^{2}$ Email:olusolaat@gmail.com \\ ${ }^{2}$ Email:murtadaogunsiji@gmail.com \\ ${ }^{3}$ Research Assistant, Department of Economics, Fountain University, Oke- \\ Osun, Osogbo, Osun State, Nigeria.
}

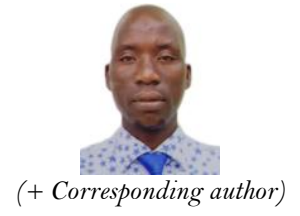

Contribution/Originality: The study employs the novel technique of non-linear autoregressive distributed lag (NARDL) to investigate the asymmetric relationship between fiscal and current account deficits. More so, the study distinguishes between budget deficit and fiscal deficit in estimations through the inclusion of borrowing, as a significant component of fiscal deficit in Nigeria.

\section{INTRODUCTION}

A higher fiscal deficit that granger causes long-run increase in the current account deficit is regarded as the twin deficit (Hashemzadeh \& Wilson, 2006; Ramu, 2017). Although with different transmission mechanisms, both the Keynesian absorption theory and the Mundell-Fleming model predicted the causal relationship between fiscal deficit and current account deficit. According to the latter theory, an increase in fiscal deficit puts upward pressure on the domestic interest rate. Due to portfolio adjustment behaviour of investors, there would be increase in capital inflow and this will translate to exchange rate appreciation. The appreciation of the exchange rate suggests an increase in aggregate income; giving the citizens the ability to demand for varieties across the globe and increase import. An increase in import leads to current account deficit; hence, the twin deficit hypothesis. The absorption theory of Keynes (1936) is similar except that a reduced taxation or increased public expenditure is considered as the basis for fiscal deficit. This increased expenditure increases aggregate income and leads to increase in imports and a worsening trade balance. 
There exists a preponderance of empirical evidence on the high correlation between fiscal deficit and current account deficit. The classification of the empirical literature is into strands of granger causality and long-run equilibrium relationships of the twin deficits. With regards to granger causality, the studies of Vyshnyak (2000), Baharumshah, Lau, and Khalid (2006) and Iyeli and Ovat (2017) validated the Keynesian thinking with a unidirectional causality that causality runs from fiscal deficit to current account deficit. On the other hand, the studies of Zengin (2000),Omoniyi, Olasunkanmi, and Babatunde (2012) and Benedict (2017) found bi-directional causality of twin deficit hypothesis. In terms of short-run and long-run equilibrium conditions, the studies of Onafowokan and Owoye (2006) and Hassan, Wajid, Mahmood, and Shahbaz (2015) found that both the fiscal deficit and current account deficit have equilibrium conditions that keep them together both for short-run situation and long-run conditions. Saleh and Chowdhury (2007) found evidence for only long-run equilibrium for a study conducted for Sri-Lanka. Šuliková, Siničáková, and Horváth (2014) found mix results of uni-direction and bidirectional causality for a study conducted for the Baltic countries of Estonia, Latvia and Lithuania.

There is no disputing that Nigeria has a long history of fiscal deficits. In fact, it is categorical to say that Nigeria has experienced growths in its fiscal deficit balances over the years, specifically, since the 1980s. With a fiscal deficit of $\$ 3.6$ Billion in 1981 to $\$ 70.27$ Billion in 1996 and a further increase to $\$ 285.10$ Billion in the year 1999, fiscal deficit in Nigeria grew to $\$ 202.72$ Billion in 2003 and by 2018 , it has increased to $\$ 3,628.10$ Billion (CBN, 2018). It is important to note that the two major components of fiscal deficits are the excess of government expenditure over its revenue in addition to total borrowings (a combination of both domestic and foreign debts). Basically, the idea for debt accumulation is for capital investment and the surplus government expenditure is also directed towards infrastructural development. Altogether, fiscal deficit should stimulate aggregate demand in the economy and further enhance economic growth. However, the supposed gains of fiscal deficit financing could be reversed if it exceeds a threshold beyond the absorptive capacity of an economy. This could translate to inflationary pressures and aggravate current account deficits. While other factors could account for the presence of current account deficits in Nigeria, the perennial years of fiscal deficits cannot be under-estimated.

On aggregate, Nigeria's balance of trade position has been of surplus balance except for some occasional periods. The periods 1981 - 1983, 1998 and 2015 - 2016 are the exceptional periods marked for oil glut, international economic sanctions and economic recession respectively. The current account deficits for these three periods ranged between $\$$ 1.4Billion and $\$ 2$ 230.9Billion. Therefore, it is pertinent that Nigeria experienced twin deficit, on the aggregate, for the periods 1981 - 1983, 1998 - 1999 and 2015 - 2016. When disaggregated, also, there is evidence of current account deficit between Nigeria's non-oil export and non-oil import since the $1980 \mathrm{~s}$ (CBN, 2018). With a focus on the non-oil components of her trade transactions, the country perpetuates the twin deficit syndrome throughout the periods since the 1980s. Consequently, this study seeks to examine the direction of causality between fiscal deficit and current account deficit and further investigates the validity of the twin deficit hypothesis for the Nigerian economy. The third objective is to ascertain how the twin deficit hypothesis has been driven by macroeconomic fundamentals in Nigeria for the period under investigation.

These objectives appear not entirely new to empirical investigations. For example, Rehman and Saeed (2017) and Iyeli and Ovat (2017) employed the use of granger causality and error correction method to investigate the relationship between the twin deficits. Also, Hashemzadeh and Wilson (2006) and Zengin (2000) employed the use of Vector Auto-regression (VAR) framework. However, these studies assumed linear relationship between fiscal deficit and current account deficit. The trend dimensions between the aggregated and disaggregated data of the twin deficits for Nigeria is an indication that nonlinear as well as asymmetric relationship cannot be ruled out for both fiscal and current account deficits. This is a novelty that has not been explored by previous studies. More so, most of the studies have confused budget deficit with fiscal deficit. Borrowing is an integral part of fiscal financing in Nigeria and its exclusion would understate the true position of fiscal balance for the Nigerian economy. In fact, this could lead to measurement error; capable of undermining the reliability and validity of the estimates obtained 
and the conclusions reached therefrom. Nonetheless, the role of macroeconomic fundamentals in driving the twin deficit has been latently investigated in the literature. This study seeks to pursue these identified gaps evident in the literature. In addition to this introductory section, the methodology is discussed in section 2.0 while estimations were carried out in section 3.0. In section 4.0, conclusions were reached and policy suggestions were provided.

\section{METHODS}

This study is anchored on the Keynesian absorption theory. The theory predicts a positive correlation between fiscal deficit and current account deficit through the interest rate and exchange rate channels. Basically, a country's national income can be consumed, saved or paid into taxes. As such;

$Y=C+S+T$

For an open economy, the national income is given as the gross domestic product plus income earned by the nationals of a country irrespective of their destination anywhere in the world.

$Y=C+I+G+N F I_{A}$

In tandem with the structure of the national income accounting, the income component of $N F I_{A}$ equates the

expenditure component of net export $(X-M)$;

$$
N F I_{A}=(X-M)
$$

Substituting Equation 3 into 2 gives;

$$
Y=C+I+G+(X-M)
$$

By national income accounting, both Equations 1 and 4 equate with the difference being considered negligible and captured as residual errors. Therefore, we have;

$$
C+I+G+(X-M)=C+S+T+\varepsilon
$$

$$
(X-M)=(S-I)+(T-G)+\varepsilon
$$

Equation 6 shows that the net export balance equals the addition of the excess of savings to investment and excess of government revenue to government expenditure. The LHS of Equation 6 is the current account balance while the RHS makes up the fiscal deficit. We have;

$$
N X(E)=f(\text { Fiscal_deficit }(R)+\varepsilon)
$$

Equation 7 presupposes that the next export is a function of the exchange rate between the trading countries while the fiscal deficit is determined by the rate of interest. Importantly also, the openness on trade is required for international trade to occur while openness on financial flows is needed for international capital transactions. Hence, Equation 7 has this openness index as control factors.

$$
N X=f(\text { fiscal_deficit, rexch, rint, topen, fopen })+\varepsilon
$$

In order to reflect price-adjusted transactions, both the rate of interest and the exchange rate are expressed in real terms. Expressing Equation 8, therefore, as an econometric model gives;

$$
n x=\beta_{0}+\beta_{1} \text { fiscal_deficit }+\beta_{2} \text { rexch }+\beta_{3} \text { rint }+\beta_{4} \text { topen }+\beta_{5} \text { fopen }+\varepsilon
$$


Where; fiscal_deficit is the fiscal deficit; exchr is the real exchange rate; int $r$ is the real rate of interest, topen is the trade openness and fopen is financial openness. $\varepsilon$ is the residual error. Equation 9 is the empirical model to investigate the twin deficit. In order to primarily investigate the asymmetric relationship between both current account and fiscal deficits, the empirical model in Equation 9 is expressed in a Non-linear Autoregressive Distributed Lag (NARDL) model of the form;

$$
n x=\beta_{0}+\delta \sum_{t=1}^{t-n} n x+\beta_{1} \sum_{t=0}^{t-n} \text { fiscal_deficit }+\beta_{2} \sum_{t=0}^{t-n} \text { rexch }+\beta_{3} \sum_{t=0}^{t-n} r \text { int }+\beta_{4} \sum_{t=0}^{t-n} \text { topen }+\beta_{5} \sum_{t=0}^{t-n} \text { fopen }+\varepsilon(10)
$$

NARDL simultaneously tests for the short- and long-run nonlinearities and considers the asymmetric distribution of time-series variables through positive and negative partial sum decompositions of the predetermined explanatory variables (Shin, Yu, \& Greenwood-Nimmo, 2014).In addition, the need to investigate the shock effects of macroeconomic fundamentals on the twin deficit suggests that a Structural Vector Auto-regression (SVAR) of the empirical model should be obtained. It is important to note that macroeconomic objectives conflict as achieving one objective delimits the attainment of another objective. The Phillip Curve describes the inverse relationship between economic growth and stability of prices. Okun's Law identified the threshold of economic growth that would translate to employment generation. As such, the interest rate serves as a unifying policy variable to achieve internal balance while the exchange rate serves as the policy variable for external balance as it remains the reference denomination for the balance of payment account. Therefore, both the rate of interest and the exchange rate are indicators of macroeconomic fundamentals. In order to address the last research objective, the shock effects of the macroeconomic fundamentals on the twin deficits will be estimated with the Structural Vector Autoregression (SVAR) model specified below:

$$
\left|\begin{array}{cccccc||c|c}
1 & 0 & 0 & 0 & 0 & 0 \\
a_{21} & 1 & 0 & 0 & 0 & 0 \\
a_{31} & a_{32} & 1 & 0 & 0 & 0 \\
a_{41} & a_{42} & a_{43} & 1 & 0 & 0 \\
a_{51} & a_{52} & a_{53} & a_{54} & 1 & 0 \\
a_{61} & a_{62} & a_{63} & a_{64} & a_{65} & 1
\end{array}\right| \begin{gathered}
n x \\
\text { fiscal_def } \\
\text { rexch } \\
\operatorname{rint} \\
\text { topen } \\
\text { fopen }
\end{gathered}|=D(L)| \begin{array}{cccccc}
1 & 0 & 0 & 0 & 0 & 0 \\
a_{21} & 1 & 0 & 0 & 0 & 0 \\
a_{31} & a_{32} & 1 & 0 & 0 & 0 \\
a_{41} & a_{42} & a_{43} & 1 & 0 & 0 \\
a_{51} & a_{52} & a_{53} & a_{54} & 1 & 0 \\
a_{61} & a_{62} & a_{63} & a_{64} & a_{65} & 1
\end{array}\left|+\begin{array}{c}
\text { Enx } \\
\text { Efiscal_def } \\
\text { Erexch } \\
\text { Erint } \\
\text { Etopen } \\
\text { Efopen }
\end{array}\right|
$$

The data scope span $1981-2018$. This period of investigation is considered more appropriate owing to the various financial reforms coupled with series of economic episodes that took place. The data for this study are sourced from the CBN (2018). The statistical properties of the data would be obtained through the conventional unit-root tests of Augmented Dickey-Fuller (ADF) and Phillip-Peron (PP). The granger causality test too will be carried out to trace the direction of causality between fiscal deficit and current account deficit; with reference to aggregated and disaggregated trade balance. This is to ascertain the possible outlier effects evidenced in the data. More so, descriptive statistics of the series would be obtained to provide more insights into the variables of analyses.

\section{RESULTS AND FINDINGS}

\subsection{Descriptive Statistics of Variables}

This section provides the statistical properties of the variables included in the model specification. These variables are the aggregate net export (ANEXP), the real exchange rate (REXCHR), the real interest rate (RINT), fiscal deficit (fiscal_deficit), trade openness (TOPEN) and financial openness (FOPEN). As evident, the average 
value of aggregate net export - an indicator for current account deficit is N1, 474.75Billion for the period under consideration. The implication is that the export component of the trade balance in Nigeria exceeds its import component when aggregated. More so, the deviation of the aggregate net export value away from its expected value is huge and not normally distributed. Precisely, the standard deviation for the aggregate net export is 2130.6 and it is platykurtic with 2.25 kurtosis value. This is a pointer to the possibility of business cycle behaviours in Nigeria as few periods of outliers in export would have reversed the possibility of many periods of current account deficit. As such, the data structure of aggregate net export would also be normalized to ascertain its appropriateness for empirical investigations. This is necessary to remove possible outlier effects.

Table-1. Statistical Properties of Variables.

\begin{tabular}{|c|c|c|c|c|c|c|}
\hline Variable & $\begin{array}{c}\text { ANEXP } \\
\text { ('Billion) }\end{array}$ & FOPEN & REXCH & RINT & TOPEN & $\begin{array}{c}\text { Fiscal } \\
\text { Deficit(A' Billion) }\end{array}$ \\
\hline Mean & 1474.751 & 1.1309 & 149.3952 & 0.1966 & 30.1951 & -39.5821 \\
\hline Std. Dev. & 2130.609 & 2.1121 & 120.0999 & 14.7859 & 12.6263 & 81.4181 \\
\hline Minimum & -2230.91 & 0.0001 & 49.7338 & -65.8572 & 7.3624 & -301.4016 \\
\hline Maximum & 5834.927 & $\begin{array}{l}6 \\
\end{array} 9885$ & 536.7732 & 18.18 & 58.918 & 32.0494 \\
\hline Skewness & 0.7464 & 1.7841 & 1.8297 & -2.5862 & -0.0354 & -2.1524 \\
\hline Kurtosis & 2.2545 & 4.6982 & 5.4907 & 11.9120 & 2.3648 & 6.5079 \\
\hline Jarcque-bera Stat. & 4.4084 & 48.8244 & 24.7245 & 0.6468 & 168.116 & 31.0257 \\
\hline Prob. values & 0.110 & 0.000 & 0.000 & 0.724 & 0.000 & 0.000 \\
\hline
\end{tabular}

Instructively, the recurring periods of oil boom occasioned by hostilities and restiveness in the international oil market would have accounted for this turn of event. However, the mean value of fiscal deficit for the corresponding period is N39.582Billion. The implication is that there was indeed fiscal deficit in Nigeria for the period under review. The corresponding mean values for both trade openness (TOPEN) and financial openness (FOPEN) suggest that the Nigerian economy is averagely more open to trading activities than to financial transactions. The average degree of financial openness is a paltry 1.13 percent while trade opens at an average 30.2 percent degree. In fact, the deviations of the mean values by2.11 for financial openness is proportionally negligible as compared to that of trade openness with 12.63 value. However, the corresponding kurtosis values of 4.70 and 2.36 for FOPEN and TOPEN respectively show that the degree of financial openness is relatively more normally distributed than that of trade openness for the period under consideration. The former is leptokurtic in distribution while the latter is platykurtic in nature.

Both the real exchange rate (REXCHR) and real interest rate (RINT) have positive mean values of 149.40 and 1.97 respectively. Their corresponding skewness values are 1.83 and -2.59 respectively. This indicates that the mean values of the price-adjusted exchange rate in Nigeria depreciated marginally while the interest rate is also below the expected market value. The implication of this is that the price-adjusted exchange rate in Nigeria would endanger competitiveness and negatively affect current account balance and balance of payment position in the country. Also, the mean value of real interest rate of 1.97 that is found to be below the expected market value strongly suggests that the price level in the Nigerian economy would affect capital inflows into the country as investors would seek a better return on their investment through arbitrage window. Although, both are leptokurtic in distribution, the distribution of the real interest over the period under consideration has thinner tail than that of the real exchange rate. This is because the kurtosis value for the former is 11.91 while that of the latter is 5.49 Table 1. The real interest skewed negatively while the real exchange rate skewed positively. This indicates that the real exchange rate depreciates more than expected while the real interest rate reduces more than expected. Altogether, it suggest that resource mobilization in the country is greatly endangered; internally and externally. 


\subsection{Test for Multi-Collinearity Issues}

The basic assumption of a classical linear regression model is that explanatory variables should be truly independent. Any perceived or noticeable multi-collinearity problem is capable of undermining the reliability and validity of the estimates obtained (Greene, 2003). In Table 2, the correlations among the variables included in the model are tabulated. Obviously, the results show that the variables are free of any multi-collinearity problem as none of the estimated coefficients is closer to the 0.9 coefficient threshold.

Table-2. Correlation Matrix of Variable.

\begin{tabular}{c|c|c|c|c|c|c}
\hline & ANEXP & FISCAL_DEFICIT & FOPEN & TOPEN & RINT & REXCH \\
\hline ANEXP & 1 & 0.2654 & -0.3642 & 0.3239 & 0.2271 & -0.2882 \\
\hline FISCAL_DEFICIT & 0.2653 & 1 & 0.1292 & -0.1578 & -0.1462 & 0.2300 \\
\hline FOPEN2 & -0.3642 & 0.1292 & 1 & -0.2509 & -0.1605 & -0.1428 \\
\hline TOPEN2 & 0.3239 & -0.1578 & -0.2509 & 1 & 0.0732 & -0.5022 \\
\hline RINT & 0.2271 & -0.1462 & -0.1605 & 0.0732 & 1 & -0.1934 \\
\hline REXCH & -0.2882 & 0.2300 & -0.1428 & -0.5022 & -0.1934 & 1 \\
\hline
\end{tabular}

The correlation coefficient between real exchange rate $(\mathrm{REXCH})$ and trade openness is the highest with 0.502 . However, this 0.502 correlation coefficient suggests a moderate correlation between the two variables. The preceding negative value suggests that the real exchange rate is inversely correlated to trade openness, and vice versa, in Nigeria. This is highly expected as both exchange rate and openness on trade are essential components of international transactions. On the whole, it suggests that there are no concerns for multi-collinearity problems for the variables included in the empirical model.

\subsection{Data Stability Condition}

The data stability condition is considered with the use of both the result of the Augmented Dickey Fuller $(\mathrm{ADF})$ and Phillip-Peron (PP) tests as presented in Table 3. Both unit-root tests indicate that the variables are a mix of $\mathrm{I}(0)$ and $\mathrm{I}(1)$. Specifically, only the real interest rate (RINT) is stationary at levels while all other variables that comprise fiscal deficit, real exchange rate $(\mathrm{REXCH})$, trade openness (TOPEN) and financial openness (FOPEN) are stationary at order 1, that is, I(1). In accordance with the analytical structure of the data generating process (DGP), the autoregressive distributed lag (ARDL) model is amenable to a mix of $\mathrm{I}(0)$ and $\mathrm{I}(1)$ series such as that that exists in this analysis where the variables included in the model for estimation are a mix of unit-root and non-unit-root variables see Table 3 .

Table-3. Unit-Root Tests.

\begin{tabular}{l|c|c|c|c|c}
\hline \multirow{2}{*}{ Variables } & \multicolumn{2}{|c|}{ ADF } & \multicolumn{2}{c}{ PP } & Decision \\
\cline { 2 - 6 } & $\mathbf{I}(\mathbf{0})$ & $\mathbf{I}(\mathbf{1})$ & $\mathbf{I}(\mathbf{0})$ & $\mathbf{I}(\mathbf{1})$ & Ho: $\mathbf{r}$ \\
\hline ANEXP & -1.512 & $-3.545^{*}$ & -1.318 & $-2.964^{* *}$ & $\mathrm{I}(1)$ \\
\hline FISCAL_DEFICIT & -2.542 & $-5.896^{*}$ & $-2.650^{* * *}$ & $-3.664^{*}$ & $\mathrm{I}(1)$ \\
\hline REXCH & -2.020 & $-4.170^{*}$ & -1.909 & $-4.116^{*}$ & $\mathrm{I}(1)$ \\
\hline RINT & $-7.160^{*}$ & - & $-6.940^{*}$ & - & $\mathrm{I}(0)$ \\
\hline TOPEN & -2.393 & $-7.977^{*}$ & -2.219 & $-8.866^{*}$ & $\mathrm{I}(1)$ \\
\hline FOPEN & -2.233 & $-4.871^{*}$ & -2.149 & $-7.684^{*}$ & $\mathrm{I}(1)$ \\
\hline $\begin{array}{l}\text { Note: *, **, *** denotes significance at } 1 \%, 5 \% \text { and } 10^{*} \% \text { levels respectively. Critical I }(0): 1 \%:-3.621 ; 5 \%:-2.943 ; 10 \%:- \\
\text { 2.610. I(1): } 1 \%:-3.627 ; 5 \%:-2.946 ; 10 \%:-2.612 .\end{array}$
\end{tabular}

The common pitfalls in modelling with the use of autoregressive distributed lag technique are to assume that the relationship between the dependent and explanatory variables is linear. However, the assumption of linearity has to be subjected to test for more reliable conclusion to be reached. More so, credence is lent to the use of nonlinear modelling structure due to the disparity observed between the aggregate and disaggregated data of current account deficits. In this study, a modelling technique that combines the test of linearity with that of autoregressive distributed lag (ARDL) would be adopted. This is the use of non-linear autoregressive distributed lag 
(NARDL) model. Prior to this, the direction of causality between fiscal deficit and current account deficit has to be ascertained. This is to indicate which variable should serve as the dependent variable and which should be the independent variable between the two in testing for the twin deficit hypothesis for the Nigerian economy.

\subsection{Direction of Causality and Model Estimations \\ 3.4.1. Pairwise Granger Causality of Twin Deficit}

It is instructive to note that the descriptive statistics provided insights as to the de-trending nature of the aggregate net export data; as an indicator for current account balance, in order to expunge the outlier effects. Also, the aggregate net export is further decomposed to capture both the oil and non-oil export components. This is important to ascertain if outlier effects that exist between the aggregate and disaggregated data structure do not converge; in terms of direction of causality. The estimates obtained for the pairwise granger causality are detailed in Table 4 and the results suggest that the direction of causality moves from fiscal deficit to current account deficit; either for the aggregated data or for the disaggregated data comprising oil and non-oil net export balance.

Table-4. Pairwise Granger Causality Tests

\begin{tabular}{|c|c|c|c|}
\hline Direction of Causality & $F-$ statistics & $\operatorname{Pr} o b|F|$ & Remarks \\
\hline fiscal_def $\not \subset$ hptrend_agnexp & 9.403 & 0.001 & fiscal_def $\rightarrow$ hptrend_agnexp \\
\hline hptrend_agnexp $\not \subset$ fiscal_def & 0.948 & 0.398 & - \\
\hline fiscal_def $\not \subset$ hptrend_nonexp & 7.081 & 0.003 & fiscal_def $\rightarrow$ hptrend_nonexp \\
\hline hptrend_nonexp $\not \subset$ fiscal_def & 0.4556 & 0.638 & - \\
\hline fiscal_def $\not \subset$ hptrend_onexp & 11.517 & 0.000 & fiscal_def $\rightarrow$ hptrend_onexp \\
\hline hptrend_onexp $\not \subset$ fiscal_def & 0.653 & 0.527 & - \\
\hline
\end{tabular}

Specifically, the hypothesis that fiscal deficit does not granger cause aggregate net export was rejected at the 1 percent level of significance. This is because the F-statistics value of 9.403 has probability value of 0.001 . The reverse causality hypothesis cannot be rejected with $0.948 \mathrm{~F}$-statistics and corresponding 0.398 probability value. This suggests that the hypothesis that aggregate net export does not granger cause fiscal deficit is valid; even when a 10 percent level of significance is considered. Similarly, the hypotheses that fiscal deficit does not granger cause non-oil net export and oil net export respectively are rejected even at the 1 percent level of significance and corresponding F-statistics values of 7.081 and 11.517 respectively. The reverse causality hypotheses in both cases that non-oil net export and oil net export respectively do not granger cause fiscal deficit are both valid; even at the 10 percent level of significance. These results indicate that in the formation of the modelling structure to investigate whether the twin hypothesis hold for the Nigerian economy, the fiscal deficit would serve as the explanatory variable while the current account deficit would serve as the dependent variable. It is also important to note that the consensus results in the direction of causality between the aggregate and disaggregated components of the net exports is an indication that either of the two is appropriate in the modelling structure of the twin deficit hypothesis. The aggregate component will be used for analyses in this study.

\subsubsection{Long Run Equilibrium Condition and Impact Analyses}

In this study, the procedure for obtaining the long-run equilibrium condition is through extraction from the pairwise regression estimates see Appendix 2. The basic parameters of the pairwise regression estimations are fit and do not violate the basic underlying assumptions of a typical regression model. The coefficient of determination suggests that the independent variables well explained the movement in the dependent variable while the $\mathrm{F}$ statistics suggests overall fitness of the model. Also, the Durbin Watson statistics strongly indicates that there is no 
problem of autocorrelation in the model. The general fitness of estimates obtained lend credence to the absence of specification error in the model. Subsequently, the long-run co-integration of the variables was ascertained and tested for asymmetry using the Wald test.

The co-integration results detailed in Table 5 show that long-run equilibrium condition exists among the variables included in the model, particularly between fiscal deficit and current account deficit. The F-statistic of 17.61 with corresponding probability value of 0.000 is higher than the upper bound critical value of 5.05 for the 1 percent level of significance. Also, the chi-square statistics of 176.12 is not just statistically significant at the 1 percent level, it is higher than the upper bound critical value of 5.05. Overall, this implies the existence of an equilibrium condition that allows both fiscal deficit and current account deficit to co-move together into the longrun situation; thereby, lends credence to the validation of the twin deficit hypothesis for the Nigerian economy see

Table 5 .

Table-5. Long-Run Equilibrium

\begin{tabular}{l|c|c}
\hline Test Statistics & \multicolumn{2}{|c}{$17.61(0.000)$} \\
\hline F-statistics & \multicolumn{2}{c}{$176.12(0.000)$} \\
\hline Chi-Square & \multicolumn{2}{c}{ Critical Values } \\
\hline & 3.74 & Upper Bound Critical Value \\
\hline Levels of Significance & Lower Bound Critical Value & 5.05 \\
\hline $1 \%$ & 2.86 & 4.01 \\
\hline $5 \%$ & 2.45 & 3.52 \\
\hline $10 \%$ & & \\
\hline
\end{tabular}

The coefficients for impact analyses alongside their corresponding probability values are detailed in Table 6 . Evidently, it is obvious that both the positive and negative changes in fiscal deficit impact positively and significantly on current account deficit as indicated by net export; even at the 1 percent level of significance. Specifically, the positive change in fiscal deficit has 21.382 coefficient with 0.000 corresponding probability value while the negative change in fiscal deficit has 7.559 coefficient and 0.001 corresponding probability value. The implication of these estimates is that the twin deficit hypothesis is valid for the Nigerian economy irrespective of the effects of sign changes between fiscal deficit and current account deficit for the Nigerian economy. This suggests that the government would have to put fiscal deficit under control if the debilitating effects of the current account have to be reduced.

Also, the degree of financial integration with other economies of the world; as measured by financial openness and indicated as FINOPEN, positively impacts on the current account deficit of the Nigerian economy. The FINOPEN has 314.6 coefficients with 0.023 probability value. This indicates that the higher the degree of financial openness, the higher the current account deficit. The implication of this is that policy makers in Nigeria are to embark on a gradual as well as sequential form of financial integration rather than an indiscriminate financial openness of the economy. In a related behaviour, the negative change in trade openness also has a significant positive impact on current account deficit in Nigeria with 84.95 coefficient and 0.003 probability value while the positive change of the trade openness impacts significantly negative on Nigeria's current account deficit at the 5 percent level (see Table 6). The different sign effects of both positive and negative changes of trade openness on current account deficits suggest that a decline in the degree of trade openness would increase the current account deficits of the Nigerian economy while an increasing degree of trade openness would reduce the value of current account deficit. These results lend credence to the potency of the real sector of the Nigerian economy in enhancing its level of competitiveness. As a result, the real sector of the Nigerian economy should be stimulated and all forms of restrictions should be fully eliminated in order to facilitate unhindered transactions of goods and services across borders. 
Table-6. Long-Run Coefficients

\begin{tabular}{l|c|c}
\hline Variable & Co-efficient & Prob. \\
\hline C & -7878.381269 & $0.023^{*}$ \\
\hline FOPEN2(-1) & 314.64417778 & $0.0226^{*}$ \\
\hline REXCHPOSITVE(-1) & 33.86943372 & $0.0031^{* *}$ \\
\hline REXCHNEGATIVE(-1) & 3.839727797 & 0.0636 \\
\hline RINTPOSITVE(-1) & 7.757127502 & 0.7857 \\
\hline RINTNEGATIVE(-1) & -42.22653829 & 0.0805 \\
\hline TOPEN2POSITVE(-1) & -96.9550493 & $0.049^{*}$ \\
\hline TOPEN2NEGATIVE(-1) & 84.95094823 & $0.0027^{* *}$ \\
\hline FISCAL_DEFICITPOSITVE(-1) & 21.38229622 & $0.0000^{* *}$ \\
\hline FISCAL_DEFICITNEGATIVE(-1) & 7.558777942 & $0.0048^{* *}$ \\
\hline Note: ** denotes significance at 1\%; * denotes significance at 5\%. & &
\end{tabular}

Similarly, both the negative and positive changes of the real exchange rate further aggravate the level of current account deficits in Nigeria. The positive change has 33.87 coefficient with 0.003 corresponding probability value while the negative change has 3.84 coefficient with 0.06 corresponding probability value; albeit barely significant. The implication is that both appreciation and depreciation of the domestic currency in tandem with the international referenced currency of the US dollar tend to further worsen the trade balance of the Nigerian economy. Intuitively, a possible explanation is that an appreciation of the domestic currency without a complementary competitive real sector cannot be helpful to the trade balance of the Nigerian economy. However, the real interest rate is considered negligible to the current account deficit in Nigeria as the attributed probability values for both the positive and negative effects are not significant at the 5 percent level. In order to lend credence to the estimates above, the Wald test for asymmetry in Table 7 shows that effects of both positive and negative changes in fiscal deficit are not same on current account deficit. The F-statistics of 86.53 with probability value of 0.000 suggests that the null hypothesis of no asymmetry should be rejected. Similarly, trade openness and real exchange rate also have asymmetric relationship with current account deficit. However, the results show that only the relationship between current account deficit and real interest rate is symmetric.

Table-7. Asymmetric effect of fiscal deficit on current account deficit.

\begin{tabular}{|c|c|c|}
\hline Variable & F-Statistic & Prob. \\
\hline Fiscal_Deficit $^{+} \&$ Fiscal_Deficit ${ }^{-}$ & 86.53 & 0.0000 \\
\hline $\mathrm{REXCH}^{+} \& \mathrm{REXCH}^{-}$ & 9.493 & 0.0081 \\
\hline $\mathrm{RINT}^{+} \& \mathrm{RINT}^{-}$ & 1.9353 & 0.186 \\
\hline $\mathrm{TOPEN}^{+} \& \mathrm{TOPEN}^{-}$ & 9.003 & 0.010 \\
\hline
\end{tabular}

\subsubsection{Estimations of SVAR and Analyses of Shock Effects}

As a robustness test, this section analyses how the twin deficit has impacted on macroeconomic fundamentals with implications drawn from the effects of both the real exchange rate and real interest rate within a structural model. With the use of the Structural Vector Auto-regression (SVAR) modelling structure, the shock effects of both the current account deficit and fiscal deficits would be analyzed on the two variables.

The result for the variance decomposition of the current account deficit ANEXP shows that the aggregate net export is strongly endogenous both in the short-run and the long run.

Thus, aggregate net export responds strongly to own shock. Both the real interest rate and the real exchange rate are strongly exogenous accounting for just $0-8 \%$ of the shock in ANEXP between year 1 and year 4 and only $10 \%$ at the end of year 10 Table 8 . This implies that a shock in current account deficit has insignificant and negligible impact on macroeconomic fundamentals represented by the real interest rate and real exchange rate.

An appreciable shock effect on the current account deficit is only traceable to the degrees of trade and financial openness in the country. This is understandably so as legal and market-based factors to open up the economy will translate to the opportunities to trade in finance, goods and services with other countries of the world. However, it 
is found that only about 10 percent and 15 percent shock effects for trade openness and financial openness respectively can be accounted for as a whopping 64 percent shock effects are still traceable to the current account deficits Table 8. This suggests that the Nigerian economy is finance-led. For the fiscal deficit, however, the current account deficit and the degree of trade openness account for substantial shock effects. At the tenth year, current account deficit account for about 21 percent shock effects while the degree of trade openness accounts for about 27 percent shock effects. The real interest rate has shock effects that stood at 10 percent at the tenth year Table 9.

Table-8. Variance Decomposition of the Current Account Deficit (ANEXP) Due to an Innovation in:

\begin{tabular}{c|c|c|c|c|c|c|c}
\hline Period & S.E. & ANEXP & Fiscal_Deficit & REXCH & RINT & TOPEN & FOPEN \\
\hline 1 & 1183.838 & 100.0000 & 0.000000 & 0.000000 & 0.000000 & 0.000000 & 0.000000 \\
\hline 2 & 1866.022 & 95.89263 & 0.117439 & 0.098049 & 1.378360 & 1.613085 & 0.900436 \\
\hline 3 & 2208.753 & 82.30548 & 0.483231 & 0.838929 & 5.223952 & 5.452985 & 5.695424 \\
\hline 4 & 2400.395 & 69.81582 & 0.578505 & 1.727701 & 7.855145 & 8.980750 & 11.04208 \\
\hline 5 & 2515.231 & 64.89857 & 0.532969 & 2.106440 & 8.621344 & 10.07634 & 13.76434 \\
\hline 6 & 2546.208 & 64.00683 & 0.689371 & 2.123387 & 8.714277 & 10.04643 & 14.41971 \\
\hline 7 & 2552.107 & 63.79429 & 0.841431 & 2.114776 & 8.713681 & 10.03715 & 14.49868 \\
\hline 8 & 2568.667 & 64.02364 & 0.855910 & 2.088003 & 8.613822 & 10.01990 & 14.39872 \\
\hline 9 & 2584.674 & 64.07554 & 0.846681 & 2.109275 & 8.528690 & 9.917029 & 14.52278 \\
\hline 10 & 2596.162 & 63.58552 & 0.842607 & 2.299561 & 8.473803 & 9.831763 & 14.96675 \\
\hline
\end{tabular}

Table-9. Variance Decomposition of Fiscal Deficit Due to an Innovation in.

\begin{tabular}{c|c|c|c|c|c|c|c}
\hline Period & S.E. & ANEXP & Fiscal_Deficit & REXCH & RINT & TOPEN & FOPEN \\
\hline 1 & 57.23261 & 9.454934 & 90.54507 & 0.000000 & 0.000000 & 0.000000 & 0.000000 \\
\hline 2 & 71.93947 & 14.09063 & 76.88036 & 2.848278 & 1.729206 & 0.652086 & 3.799440 \\
\hline 3 & 84.82750 & 19.07816 & 55.50751 & 2.653286 & 2.310769 & 15.88460 & 4.565681 \\
\hline 4 & 92.95828 & 21.45146 & 46.43652 & 2.332115 & 3.073244 & 22.18673 & 4.519926 \\
\hline 5 & 98.15775 & 21.80708 & 41.65656 & 2.134332 & 5.622206 & 24.64945 & 4.130375 \\
\hline 6 & 101.7394 & 21.27097 & 38.84632 & 2.172795 & 8.416351 & 25.24286 & 4.050706 \\
\hline 7 & 104.2257 & 20.77761 & 37.09403 & 2.523372 & 9.604927 & 25.90266 & 4.097400 \\
\hline 8 & 106.2358 & 20.53173 & 35.72360 & 2.964605 & 10.01922 & 26.47995 & 4.280904 \\
\hline 9 & 107.9636 & 20.55260 & 34.59012 & 3.349295 & 10.03904 & 27.01441 & 4.454538 \\
\hline 10 & 109.4111 & 20.66740 & 33.68107 & 3.534514 & 9.994898 & 27.43762 & 4.684485 \\
\hline
\end{tabular}

Specifically, the result for the variance decomposition of fiscal deficit indicates that fiscal deficit is weakly endogenous in the long run. From year 4 upwards, fiscal deficit responds weakly to its own shock. Both the real interest rate and real exchange rate account for a negligible percentage of the shock in fiscal deficit similar to their insignificant contribution to current account deficit. Each of the current account deficit and trade openness accounts for a significant percentage of the shock in fiscal deficit with over $20 \%$ contribution from year 4 Table 9 . This corroborates previous results on the validation of the twin deficit hypothesis for the Nigerian economy.

\section{CONCLUSIONS}

The twin-deficit hypothesis is validated for the Nigerian economy as indicated from results obtained through the granger causality tests, non-linear autoregressive distributed lag and the structural vector autoregressive models. In fact, results from the granger causality test suggest that the direction of causality was found to move from the fiscal deficits to current account deficit. Nonetheless, the results from the descriptive statistics gave pointers to the fact that the price-adjusted exchange rate endangers the level of competitiveness of the Nigerian economy while the real interest rate gave incentive to investors to engage in arbitrage activities for higher return on their investment elsewhere. The shock effects between the two variables also lend credence to the robustness of these results. The shock effects from both the current account deficits and fiscal deficit in Nigeria are majorly selfinflicting as no shock from macroeconomic fundamentals were found to be substantial enough. However, the major drivers of twin-deficit in Nigeria were found to be the degrees of trade and financial openness in the country. 
Therefore, it is recommended that policy makers in Nigeria should ensure that the degrees of financial and trade openness in Nigeria should be sequenced in such a way that the overall health of the economy would be guaranteed.

Funding: This study received no specific financial support.

Competing Interests: The authors declare that they have no competing interests.

Acknowledgement: All authors contributed equally to the conception and design of the study.

\section{REFERENCES}

Baharumshah, A. Z., Lau, E., \& Khalid, A. M. (2006). Testing twin deficits hypothesis using VARs and variance decomposition. Journal of the Asia Pacific Economy, 11(3), 331-354. Available at: https://doi.org/10.1080/13547860600764245.

Benedict, I. (2017). Causality test of budget and current account deficits in Nigeria: Evidence from Toda and Yamamoto modified wald analysis. Advances in Social Sciences Research Journal, 4(6), 238-247. Available at: https://doi.org/10.14738/assrj.46.2881.

CBN. (2018). Central bank of Nigeria annual statistical bulletin. Abuja, Nigeria: Central Bank of Nigeria.

Greene, W. (2003). Econometric analysis (5th ed.). New Jersey: Prentice Hall.

Hashemzadeh, N., \& Wilson, L. (2006). The dynamics of current account and budget deficits in selected countries in the Middle East and North Africa. International Research Journal of Finance and Economics, 5, 111-129.

Hassan, M. S., Wajid, A., Mahmood, H., \& Shahbaz, M. (2015). Testing relevance of twin deficit for a transition economy like Pakistan. Transylvanian Review of Administrative Sciences, 11(46), 91-106.

Iyeli, I. I., \& Ovat, O. O. (2017). Budget deficits and current account disequilibrium in Nigeria: An econometric investigation. International Journal of Development and Economic Sustainability, 5(4), 31-43.

Keynes, J. M. (1936). The general theory of employment, interest and money. London: Macmillan.

Omoniyi, O. S., Olasunkanmi, O. I., \& Babatunde, O. A. (2012). Empirical analysis of Twins' deficits in Nigeria. IJMBS, 2(3), 3841.

Onafowokan, O. A., \& Owoye, O. (2006). An empirical investigation of budget and trade deficits: The case of Nigeria. Journal of Developing Areas, 39(2), 153-174. Available at: https://doi.org/10.1353/jda.2006.0009.

Ramu, A. M. (2017). Twin deficits' hypothesis: An assessment of relationship and transmission mechanism in India. Foreign Trade Review, 52(1), 15-29. Available at: https://doi.org/10.1177/0015732516650825.

Rehman, A., \& Saeed, S. (2017). Validity of twin deficit hypothesis in case of Pakistan: Using different co-integration techniques. Economics, Commerce and Trade Management: An International Journal, 1(1), 45-57.

Saleh, A. S., \& Chowdhury, K. (2007). Testing the Keynesian proposition of twin deficits in the presence of trade liberalisation: Evidence from Sri Lanka. University of Wollongong. Economic Working Paper Series. WP 07-09, 1-3.

Shin, Y., Yu, B., \& Greenwood-Nimmo, M. (2014). Modelling asymmetric cointegration and dynamic multipliers in a nonlinear ARDL framework. In: Sickles R., Horrace W. (eds) Festschrift in Honor of Peter Schmidt. New York: Springer.

Šuliková, V., Siničáková, M., \& Horváth, D. (2014). Twin deficits in small open baltic economies. Panoeconomicus, 61(2), $227-239$. Available at: https://doi.org/10.2298/pan1402227s.

Vyshnyak, O. (2000). Twin deficit hypothesis: The case of Ukraine. Masters of Art Thesis Submitted to the National University "Kyiv- Mohyla Academy", Ukraine.

Zengin, A. (2000). The twin deficits hypothesis (The Turkish Case). Zonguldak karaelmas university. Department of economics. Turkey: Zonguldak. 
Pairwise Granger Causality Tests

Date: 09/09/20 Time: 15:23

Sample: 19812018

Lags: 2

Null Hypothesis:

FISCAL_DEFICIT does not Granger Cause HPTRENDo1

HPTRENDo1 does not Granger Cause FISCAL_DEFICIT

FISCAL_DEFICIT does not Granger Cause HPTRENDO2_NONEXP 36

HPTRENDO2_NONEXP does not Granger Cause FISCAL_DEFICIT

FISCAL_DEFICIT does not Granger Cause HPTREND03_ONEXP

HPTRENDO3_ONEXP does not Granger Cause FISCAL_DEFICIT

\begin{tabular}{|c|c|c|}
\hline Obs & F-Statistic & Prob. \\
\hline \multirow[t]{2}{*}{36} & 9.40310 & 0.0006 \\
\hline & 0.94804 & 0.3984 \\
\hline \multirow[t]{2}{*}{36} & 7.08078 & 0.0029 \\
\hline & 0.45557 & 0.6383 \\
\hline \multirow[t]{2}{*}{36} & 11.5167 & 0.0002 \\
\hline & 0.65338 & 0.5273 \\
\hline
\end{tabular}

\section{$\mathbf{S}$}

Appendix-2. Pairwise regression estimates

\begin{tabular}{l|c|c|c}
\hline Variable & Co-efficient & t-Statistic & Prob. \\
\hline C & -8656.269 & -2.552976 & 0.023 \\
\hline ANEXP(-1) & -1.098737 & -11.26031 & 0.0000 \\
\hline FOPEN(-1) & 345.7112 & 2.56111 & 0.0226 \\
\hline REXCHPOSITIVE(-1) & 37.2136 & 3.559027 & 0.0031 \\
\hline REXCHNEGATIVE(-1) & 4.218851 & 2.01419 & 0.0636 \\
\hline RINTPOSITIVE(-1) & 8.523043 & 0.277183 & 0.7857 \\
\hline RINTNEGATIVE(-1) & -46.39586 & -1.883951 & 0.0805 \\
\hline TOPENPOSITIVE(-1) & -106.5281 & -2.155668 & 0.049 \\
\hline TOPENNEGATIVE(-1) & 93.33875 & 3.641448 & 0.0027 \\
\hline FISCAL_DEFICITPOSITIVE(-1) & 23.49352 & 7.216784 & 0.0000 \\
\hline RISCAL_DEFICITNEGATIVE(-1) & 8.305109 & 3.348682 & 0.0048 \\
\hline Adj. R-squared & \multicolumn{3}{|c}{0.946873} \\
\hline F-statistics & \multicolumn{3}{|c}{0.874771} \\
\hline Prob. (F-stat.) & \multicolumn{3}{|c}{0.000007} \\
\hline Durbin-Watson stat & \multicolumn{3}{|}{} \\
\hline
\end{tabular}

Views and opinions expressed in this article are the views and opinions of the author(s), Quarterly Journal of Econometrics Research shall not be responsible or answerable for any loss, damage or liability etc. caused in relation to/arising out of the use of the content. 